\title{
The Construction Of Identity In The Post-Secular States: The Case Of Turkey And Indonesia
}

\author{
Eva Mushoffa \\ Department of International Relations \\ FISIP UIN Syarif Hidayatullah Jakarta
}

\begin{abstract}
The literature on post-secularism in global politics has pointed to the underlying problem of identity construction experienced by Muslim majority states with regards to Islamic element. In this context, Turkey and Indonesia provided evidence that Islamic element can hardly be excluded as the basic character of the state, despite its secular nature. More interestingly, as the two countries strived to embolden democratic character, the articulation of Islamic element continue to experience wax and wane depending on the political context experienced by the religious group.

This article aims at shedding light on the insertion of Islamic element in Turkey's and Indonesia's state identity. This paper will explore the tension between secularist and Islamist groups in Indonesia and Turkey during the late 1960s and to 1970s respectively as the pretext within which Muslim groups experienced marginalization. But later development both in Indonesia and Turkey has allowed for their consolidation, thanks to the more democratic environment. Nevertheless, in the case of Indonesia, the consolidation of Islamic identity did not usher Islamic political parties to seize power, while Turkey witnessed the ascendency of the AKP (Adalet ve Kalkınma Partisi) the offspring of Islamist party; Refah and Fezilet party once existed in the 1980s.
\end{abstract}

Keyword : Identity construction, State identity, Muslim Group, Islam and democracy

\section{INTRODUCTION}

The struggle for the insertion of Islam as part of public life has long been recorded in Muslim majority states such as Indonesia and Turkey which are constitutionally secular.

The place of Islam in Indonesia's constitution has long been questioned. Although the Muslim groups accepted the founding fathers' decision to establish 'non-religious state', without preferential treatment for particular religion [1] and Pancasila as a sole ideology at the birth of the Republic in 1945 [2], the post-Independent Indonesia witnessed tensed relations between the state and Muslim groups that benefitted the latter less. In fact, the raising of the New Order regime to some extent was accelerated by its flexibility to accommodate the religious demand of Islamic groups. Soon after seizing power, Soeharto, aiming to diminish the influence of Indonesian communist party, opened the room for dialogue with the Muslim groups. He provided more religious interpretation of Pancasila as he emphasized on the implementation of the principle of 'believe in God' in other four remaining principles [3]. Yet Soeharto subsequently took Pancasila as one of the ideological pillars of his regime and gradually transformed it into an all-encompassing philosophy of life intended to maintain the regime administration.
In Turkey, it is important to note that the roots of Islamist ideology seem to remain strong among the Turkish people, despite the marginalization of religion undertaken by Atatürk in the establishment of a modern state in 1923. This can be seen in the quest for Islamic identity that has constantly challenged Turkish political life thereafter. Çelebi argues that the modernization, which was strongly tied to Atatürk's vision of Western civilization, failed to inculcate secular identity among Turkish people in certain areas [4]. According to Çelebi, Atatürk's secularization project was based on laicism which was not irreligion but a de-emphasizing of Islam from the public and political sphere [4]. For this reason, the state had total control over religious life through the establishment of the Directorate of Religious Affairs which administered the places of worship (cami). Interestingly, the state was also involved in the nationalization of religion in many other ways, even going so far as to define 'Turkish citizens as Muslim Sunni Turks' [4]. As a result, there was strong resistance among religious groups in general against the secularization and homogenization of religious life enforced by the state which had gradually encouraged them to reassert Islam on to Turkey’s social, economic, and political stages [5].

The aim of this paper is to fill the academic gap regarding how Islamic identity is renegotiated within the limited space provided by the secular government in Muslim majority states. Therefore, this article will answer at least three questions: How is Islamic identity constructed in Indonesia's and Turkey's public life? What factors allow for the emerging of Islamic identity in Indonesia's and Turkey's public life? When the invocation of Islam by the elites of Muslim groups lean towards the more robust articulation of Islamic values in the public sphere.

This article unfolds in three sections. The first section explores the methodological issues addressing conceptual framework of Islam, identity and their trouble implementation within national secular Muslim states. The second part explains the socio-political dynamics in Indonesia and Turkey in the late 1960s and the late 1980s respectively during which the regime in both countries suppressed the attempts by the religious group to control political power. This section also investigates the process of renegotiation between the religious group within limited opportunity provided by the secular government. This article ends with the discussion of the current development in both Indonesia and Turkey concerning the relations between the state and the religious groups. 


\section{Islam, identity and the problem of national-secular Muslim states}

Unlike other religions such as Christianity, Islam is perceived as a faith system (din) which provides moral guidelines for all areas of life. Thus, for many Muslims, there is no separation between religion and politics [6]. Yet how does the religion come into politics is a matter of debate? Nonetheless, one can hardly exclude the importance of religious element in the formation of the identity of much Middle Eastern states which are predominantly Muslim.

Since the dissolution of the Ottoman empire, Muslim states in the Middle Eastern and other Third World countries have suffered from the problem of the state-building project which derived from the attempts by elites in those states to pull many transnational elements into the national imagery or transform sub-national particles into a forced national identity [7]. In this context, following Saideman's power elite/instrumental model [7], national identity in many Muslim states is the business of politically savvy and power-hungry political elites who engineer and manipulate contending nationalism in ways that best suit their interest [7]. Yet the formation of such national identity is not static, for occasionally bottom-up factors such as social movements, political activists, intellectual undercurrents and new ideas pose a challenge for the dominant role of the elites. This is particularly relevant when both state and societal groups dispute the meanings and the expectation of already agreed national identity. King Hussein of Jordan in 1950s is the case in point when he thought that the symbol of Arab nationalism would render him more legitimacy at the time many societal groups proposed otherwise alternative [7].

While in the contemporary Middle Eastern states, one cannot exclude the influences of statism, Islamism and Arabism in shaping the identity of the state, in many other parts of Muslim majority states, the question of Islamism also renders consideration. Particularly as the state or the regime who took the upper hand to determine the national identity refused to draw a formal link between religious element such Islam and the state identity. Therefore, as suggested by Telhami and Barnett, the problem of the 'menu of choice' in the construction of identity in Muslim states, often lead to identity conflict which could occur under two conditions: first, when certain development provide actors with the choice of demands "imposed by one identity and those imposed by another" and second when the new historical conditions is no longer able to sustain "the collective self". Within this circumstances, the 'menu of choice' might be blurred and interpolated in new ways, might be arranged hierarchically and might occasionally conflict.

\section{The trouble relation between Islam and state in Indonesia and Turkey}

As indicated earlier the failure of the existing regime to accommodate the demand for inserting religious element formally as the state identity had given rise for the emergence of what Saidemen called identity conflict, which led to challenge for the authoritarian regime in Indonesia's case and the ascendency of Muslim-backed political party, the AKP in Turkish political leadership.

In Indonesia, the acceptance of Pancasila as the sole basis of the state and its apparatus by the Muslim groups was followed by the subsequent marginalization of the Muslim groups from political life, as the Soeharto administration reversed the accommodating approach it employed in the beginning to the"de-Islamizing" strategy by downsizing the existing political parties in 1970. This policy was made by Soeharto as he feared of the opposition and the resurgence of Islamic groups, particularly, the large Islamic organization such as Nahdlatul Ulama (NU) who perceived that Pancasila was being used by the government to undermine the influence of the Islamic parties. The attempt to diminish formal role of the Muslim group from political arena was then facilitated by the controversial legislation proposed 1982 and formally adopted in 1985 to ensure that all political parties and massbased organizations accepted Pancasila as their asas tunggal (sole foundation) [1]. By 1985-1986, Pancasila was formally adopted by all major social, political and religious organizations, as their sole philosophical foundation. The NU for its part eventually adopted Pancasila as its sole foundation on the basis of the compromise with the government which recognized that hand-made ideology would never replace religion. Organizations which had not accepted Pancasila as their ideological basis were disbanded by the government [1].

Nevertheless, despite such systematic marginalization of Muslim groups in the political arena, their influence was still evidence as they sought to control cultural apparatus which essentially function to challenge the existing institution by strengthening their social role in a less formal way. Therefore, in the next stage, many Islamic organizations such as NU and Muhammadiyah turned to program social services and the religious proselytization or dakwah in society. Thus, strengthened their position culturally.

In fact, by and large, the successful attempt by the Muslim groups to consolidate their cultural role has been due to the existence of the Pesantren (Islamic Boarding Schools) which are the main apparatus for Islamic organizations to maintain their positions in the society. In this context, the link between the Santri (student) and the Kyai (Religious leader of the Pesantren) continues for a lifetime. This, in turn, strengthened the root of Islamic culture, as those Santris actively involved in the society after their graduations from the Pesantren. Most often, some Santris established community-based groups in their neighborhood under the patronage of the Kyais [9]. Furthermore, some of the welleducated Santris who managed to get employed in civil services, universities and many other white collar jobs, have significantly contributed to the process of Islamic intensification among the middle class and above. These activities involved a small number of people, yet they gradually included a significant number of people. Thus, within this process, what Azra termed as 'organic Islamisation' 
has taken place, among the Middle Class including those in bureaucratic offices [10].

However, the inconsistent approach employed by the government following its rivalry with the military wing resulted in once again the rapprochement policy toward Islam in 1990s. It was during these periods, the Council of Indonesian Ulama (MUI) and the Association of Indonesian Muslim Intellectuals (ICMI) demonstrated what Hefner called "statist Islam" that involved the government as the major sponsor [8]. Nevertheless, the present of those state-sponsored organisations remained problematic as the commitment to serve the ruling government became their main agenda.

The post- Soeharto reformasi era marked the new phase of Indonesia's democratic life of which allows for the renegotiation of the articulation of Islamic identity in multiple ways. However, it is important to note that these circumstances had not led the Muslim groups to consolidate their position and demand for the formal adoption of Islamic identity in the state legislations as might be expected. Instead, the articulation of Islamic element has been more fragmented through mainly the emergence of Islamist and nationalist political parties addressing Muslim voters and the blossoming of various Islamic groups which do not only abandoned Pancasila but also require the implementation of Shari'ah. Therefore, following the abolition of the three party system previously implemented by Soeharto, Indonesia has witnessed not only the emergence of numerous political parties grabbing for Muslim constituents but also an increased number of Islamic base-organizations and their strengthening roles. In the case of political parties, Mujani et al. observed that santriaffiliated figure started to play important roles not only in the Islamist-based and Muslim-based political parties such as PPP, PKS, PKB, and PAN but also in the nationalist political party such as Golkar [12]. Therefore at this point, Islamic identity in Indonesia has been more diffused across political parties and mass organization.

In Turkey, although secularism had become embedded in Kemalist Modernization project following the establishment of the Republic of Turkey in 1923, it failed to uproot the Islamic character of the country. Yavuz argued that the strong embodiment of Islamic identity among Turkish was due to the ability of the Muslim groups to channel their aspiration through Islamic social movement which helped to reconstitute identities, institutional structures, ways of life and the moral code of society through participating, influencing or controlling cultural, educational and economic sphere. In this context, the opportunity space essentially bound multisided of Muslim agents and other oppressed groups including Kurds to amplify the network of shared meaning and associational life [13]. This movement subsequently developed activities that were autonomous from the state control.

There are two models of Islamic social movements operated in Turkey: a state-oriented Islamic movement and a society-oriented Islamic movement. The former seek to change the society from above i.e., using the state; the welfare (refah) party led by Necmetin Erbakan in 1983-1998 was of this type. Meanwhile, the latter is concerned with the transformation of the society by addressing microlevel consciousness of individuals involving religious rituals that collectively create shared moral discourse; the Neksibendi order and the Nur (Said Nursi) movement fall under this category. Among strategies employed by the former is forming Islamic political parties or alliances with other parties, while the latter maximizing new opportunity space in the market and media. It is important to note here that the societyoriented Islamic movement in the latter development undertook inward reform allowing the intersection between material prosperity and spiritual goals. Furthermore, this group politically also supported Islamist political parties such National Order Party which was later turned into the Welfare party.

It is also important to note that the proponents of these two distinct Islamic social movements gained momentum to ally an with the formal political support at the establishment of the AKP which paved the way for Recep Tayyip Erdoğan to win the election as the Prime Minister.

The AKP shared its ideological linkage with the Millî Görüş through its influential elites such as Erdoğan and Abdullah Gül who were previously active members of this movement. Yet both figures were inspired to reform the ideological base of the party and broke away from the Refah (welfare) party led by Necmettin Erbakan and its successive offspring, the Fazilet (virtue) party. Unlike the Millî Görüş movement which perceived strong opposition to closer relations with the Western states and institutions, mainly the US and Europe, The AKP had reformed this outlook significantly to promote the set of ideal norms shared by Western countries such as democracy, human rights, the rule of law, and gender rights. Equally important, the AKP also embraced global integration and focused on liberalization and the market economy at home. With this, instead of pursuing the binary vision between the West and the Islamic world as maintained by the Refah party, the AKP has shared common interests with the West and world communities through cooperation and partnership. The AKP at this stage also gained supports from Gülen movement which much of the followers of the Nur movement affiliated with. Therefore, at this stage Islamic identity in Turkey was fully consolidated in a formal way as to facilitate to the ascendancy of the AKP in the hitherto Turkish political leadership.

\section{Discussion}

Recent evidence demonstrated the ongoing process of renegotiation of Islamic element both in Indonesia and Turkey. The later portrayed the declining support for the AKP as demonstrated in the breakup of the coalition between the AKP and the Gulen movement which previously helped the AKP rise to power. Such breakup has not only divided the Turks into those who are pro-the ruling AKP and those who are against it, but also threaten the social cohesion previously prevailed, as the Kurdish group also withdrew their support for the AKP. As for Indonesia, the Blasphemy case involving Chinese ex-Governor of Jakarta Basuki Cahaya Purnama has 
revealed once again the insistence of Islamist group to dictate their agenda in the more formal way.

Drawing on the comparison between Indonesia's and Turkey's cases, this article argues that Islamic element would be continuously renegotiated in the wake of unfolding events that would either bring Islamic element polarized or consolidated. From the comparison, this article also recognizes the mixture of factors that affect the development of a particular national identity at a particular point in time. Equally important, Indonesia and Turkey depict the postsecular Muslim states in which Muslim groups continue the search for a rational balance between religiosity and secularity. Nevertheless, their religious discourse will be determined by the degree to which they could manifest their faith in a flexible fashion and their ability to reproduce themselves in the new spaces and forms of communication.

\section{REFERENCE}

[1] Ramage, Douglas E. Politics in Indonesia: Democracy, Islam and the Ideology of Tolerance, London. Routledge. 1995.

[2] Zifirdaus Adnan, "Islamic Religion: Yes, Islamic (Political) Ideology: No!, Islam and the State in Indonesia", in State and Civil Society in Indonesia, Arief Budiman, ed. Melbourne: Centre of Southeast Asian Studies Monash University, 1990.

[3] Pranowo, M. Bambang, "Which Islam and Which Pancasila? Islam and th in State and Civil Society in Indonesia, Arief Budiman, ed. Melbourne: Centre of Southeast Asian Studies Monash University, 1990, pp, 492-494.

[4] Çelebi, B. The Failure of Assertive Secularization Project in Turkey. Turkish Journal of Politics: 2 (1), pp. 89-98. 2011.

[5] Fuller, G. E. Turkey's strategic model: myths and realities. The Washington Quarterly: 27(3), pp. 51-64. 2004.

[6] Mandville, Peter, "Islam and International Relations in the Middle East: from umma to nation states," in International Relations of the Middle East, Louise Fawcett, ed. Oxford: Oxford University Press, 2009, pp. 171-187.

[7] Telhami, S., Barnett, M. "Introduction: identity and foreign policy in the Middle East," in Identity and foreign policy in the Middle East, Tehami, S., Barnett, M. Eds. Itacha: Cornel University Press, 2002, pp. 1-25. $\square$

[8] Hefner, Robert W., Public Islam and the problem of democratization. Sociology of Religion, (62) 4: 491-514, 2001.

[9] Hiroko Horikoshi, Kyai dan Perubahan Social (Jakarta: Perhimpunan Pengembangan Pesantren dan Masyarakat, 1987), 198.

[11] Azyumardi Azra, Islam Reformis: Dinamika Intelektual dan Gerakan (Jakarta: Rajawali press, 1999)

[12] Mujani, Syaiful, R. William Liddle, Kuskrido Ambardi, Kuasa Rakyat. Jakarta: Mizan. 2011.

[13] Yavuz, M. Hakan. Islamic Political identity in Turkey, Oxford: Oxford University Press, 2003. 